\title{
Mechanical resistance, biometric and physicochemical characteristics of tomato cultivars for industrial processing
}

\author{
Darlene Ana de Paula VIEIRA ${ }^{1}$ (D), Márcio Caliari ${ }^{2 *}$, Eli Regina Barboza de SOUZA², \\ Manoel Soares SOARES JÚNIOR ${ }^{2}$
}

\begin{abstract}
In order to help the choice and recommendation of cultivars with the greater mechanical resistance of fruits, this research aimed to determine the mechanical resistance and biometric and physicochemical characteristics of tomato cultivars for industrial processing. Eleven processing tomato cultivar fruits cultivar were used (IT761, H9992, H9553, AP533, Advance, N901, BR-Sena, U2006, HY26, HY37 and HY68). Tomatoes firmness was influenced by several factors, including thickness, epidermal cell shape, and internal structures. In general terms, fruits more resistant to compression and puncture presented low longitudinal diameter (55-59 mm), cross-sectional diameter $(42-45 \mathrm{~mm})$, scar diameter $(5.8-6.6 \mathrm{~mm})$, pericarp thickness $(5.9-7.7 \mathrm{~mm})$,

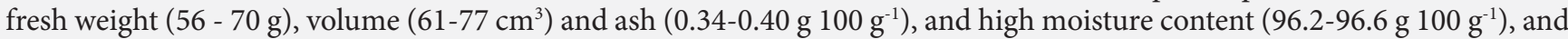

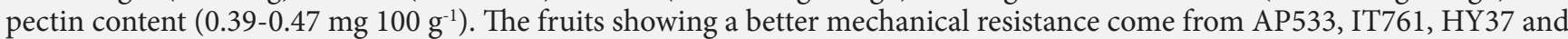
H9992 cultivars, which should be recommended for cultivation in order to reduce losses during harvest, bulk handling and transportation.
\end{abstract}

Keywords: Solanum lycopersicum L.; epidermis; fruit size; puncture; peduncle scar.

Practical Application: The fruits showing a better set of mechanical properties (more resistant fruits) come from AP533, IT761, HY37 and H9992 cultivars, which should be recommended for cultivation in order to reduce losses during harvest, bulk handling and transportation.

\section{Introduction}

Tomato fruit (Solanum lycopersicum L.) is valuable as raw material for industry, being transformed in several intermediate products (concentrated pulps and cubes), and final products (extracts, sauces, juices, etc.). Harvesting and transport operations can cause damage to fruit and large losses. Thus, understanding the responses to mechanical stimuli and respective correlation with morphological and chemical characteristics of plant materials can help improving methods and technologies to reduce losses from those steps (Shirmohammadi et al., 2014).

Tomato firmness can be influenced by epidermis thickness, cell shape, and internal structures (Li \& Thomas, 2016; Radzevičius et al., 2016). The firmness of fruit pulp is also determined by cohesion strength between pectins, which is modified by the action of pectinolytic enzymes, converting from insoluble to soluble form, resulting in a loss of cohesion between cells, and therefore softening ripe fruit (Pirrello et al., 2009).

Tomato firmness under compression and skin puncture are mechanical properties relevant on characterization of processing tomatoes and are related to ripening rate and susceptibility to mechanical damage during harvest and transport ( $\mathrm{Li}$ et al., 2017; Stropek \& Golacki, 2015), taking into account that fruits are exposed to mechanical stress during those operations that can cause damage by cutting and/or crushing, and therefore causing qualitative and quantitative losses (Dimitrios et al., 2018; Viskelis et al., 2015).
Several processing tomato cultivars are available, and it is crucial to know if the fruits coming from those genotypes are strong enough to withstand mechanical stress and reduce breaking during mechanical harvesting and transport. In order to help the choice and recommendation of cultivars with the greater mechanical resistant, this research aimed to determine the biometric characteristics, physicochemical and mechanical characteristics of tomato cultivars for industrial processing.

\section{Materials and methods}

\subsection{Material}

The fruits of industrial tomato cultivars (IT761, H9992, H9553, AP533, Advance, N901, BRSena, U2006, HY26, HY37 and HY68) used in this study were donated by Cargill Agrícola S.A., from the experimental farm, located in Hidrolândia, Goiás, Brazil.

\subsection{Harvesting and sample preparation}

The fruits were sampled from the third and fourth positions of the plant and third cluster were used. Three samples for each cultivar (with 10 fruits each sample) were evaluated in relation to biometrical and physicochemical characteristics, and another 10 fruits for each mechanical characteristic test (compression 
of fruit in standing and lying position, and puncture). Fruits were manually harvested from June to September 2013, packed in low density polyethylene (LDPE) bags, properly coded, and immediately transported to the Plant Products Processing Laboratory (School of Agronomy, Federal University of Goiás). Tomatoes were manually selected regarding appearance, lack of injuries, rots and degree of ripeness, regardless of size. Then fruits were washed to remove surface dirt, rinsed under running water, submerged for $20 \mathrm{~min}$ in sodium hypochlorite solution $150 \mathrm{mg} \mathrm{L}^{-1}$ and left to dry naturally on screen tray.

\subsection{Biometric characteristics and epidermal thickness}

Fruit longitudinal diameter, cross-sectional diameter, peduncle scar and pericarp thickness were measured using a digital caliper, volume by the water displacement method, fresh weight with digital analytical balance (0.001 g precision), and density was calculated by the ratio of volume to fresh weight.

For epidermal thickness, $1 \mathrm{~g}$ samples of tomato pulp were

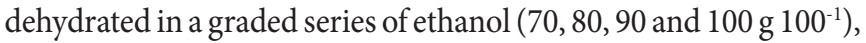
remaining for $20 \mathrm{~min}$ in each solution, and finished being dried in a critical point dryer (Autosamdri', 815, Series A, Rockville, USA), with $\mathrm{CO}_{2}$, mounted on sample holder (stub), metallized with gold, and then examined and micrographed by electron micrography in Scanning Electron Microscope (Jeol, JSM - 6610, Akishima, Japan). Epidermis measuring was carried out based on micrographic pictures (300 X magnification) using ImageJ, a public-domain software developed by the National Institutes of Health. (Schneider et al., 2012). Epidermal thickness was selected and automatically measured after scale calibration. Thirty readings were obtained from 10 micrographic pictures.

\subsection{Physicochemical characteristics}

Moisture data was obtained by drying in air-circulating oven at $105^{\circ} \mathrm{C}$ to constant weight, and ash data by incineration in muffle furnace for $6 \mathrm{~h}$ at $550^{\circ} \mathrm{C}$, both according to the Association of Official Analytical Chemists methods (Association of Official Analytical Chemists, 2012). Pectin was extracted according to McCready \& McComb (1952) and pectin total content was determined by spectrophotometry according to Blumenkrantz \& Asboe-Hansen (1973) technique, with results expressed as mg $100 \mathrm{~g}^{-1}$ of fruit galacturonic acid.

\subsection{Mechanical and textural properties}

Mechanical and textural properties were analyzed immediately after harvest using texturometer (TA, TA-XT Plus, Surrey England), by compressing fruit in standing and lying positions, and by puncturing fruit in lying position applying a normal force in equatorial area. Deformation was $50 \%$ compared to the initial fruit height. The speed in pre-test, test and post-test were $2 \mathrm{~mm} \mathrm{~s}^{-1}, 1 \mathrm{~mm} \mathrm{~s}^{-1}$, and $10 \mathrm{~mm} \mathrm{~s}^{-1}$, respectively. The average sample height of fruit in standing position was $100 \mathrm{~mm}$, and $70 \mathrm{~mm}$ for fruit in lying position. Square probe $(10 \times 10 \mathrm{~mm})$ (P100) was used for compressive test, and cylindrical probe of $5 \mathrm{~mm}$ of diameter (P5S) for puncture test. Analyses were performed at $25^{\circ} \mathrm{C}$. The firmness of skin and pulp under compression kept in standing and lying positions, and firmness by puncture of skin and pulp, were calculated by Equations 1 and 2, respectively.

$F=\frac{F m}{\Delta}$

$F=\frac{L m}{\Delta}$

In which: firmness $\left(\mathrm{N} \mathrm{mm}^{-1}\right) ; \mathrm{Fm}=$ breaking force of fruit epidermis; and $\mathrm{Lm}=$ breaking force of fruit pulp, $\Delta=$ fruit displacement or deformation.

\subsection{Statistical analysis}

Results were submitted to analysis of variance (ANOVA) and Tukey test at 5\% level. Pearson correlation was established between all variables. A free software Assistat 7.7 beta was used.

\section{Results and discussion}

\subsection{Biometrical and physicochemical characteristics}

All biometrical characteristics of fruit significantly varied among cultivars $(\mathrm{p} \leq 0.05)$. Tomatoes longitudinal diameter ranged $25.1 \%$, from 54.99 to $68.80 \mathrm{~mm}$ with the smallest values observed in H9992, HY26, HY37 and HY68 cultivars, while larger values occurred in BRSena and U2006 cultivars (Table 1). The longitudinal fruit diameter was negatively correlated $\left(-0.61^{\star}\right)$ with pulp firmness under compression of fruit in standing position. The cross-sectional diameter ranged from 41.78 to $51.77 \mathrm{~mm}$ (23.91\%), with U2006, HY68 and Advance cultivars showing the largest values, and AP533 BRSena, HY37 and H9992 cultivars showing the smallest. The cross-sectional diameter was positively correlated with pericarp thickness $\left(0.66^{\star}\right)$, peduncle scar diameter $\left(0.80^{\star *}\right)$, fresh weight $\left(0.89^{* *}\right)$, and fruit volume $\left(0.78^{* *}\right)$; in the other hand, cross-sectional diameter was negatively correlated with skin firmness under compression of fruit in lying position $\left(-0.75^{\star *}\right)$.

Thus, the dimensions, fresh weight, and volume are important for mechanical properties of processing tomatoes and should be considered for cultivar selection, as the smaller the size, the higher the skin resistance to compression of fruit in lying position. The peduncle scar measure ranged from $5.74 \mathrm{~mm}$ to $8.38 \mathrm{~mm}$, where HY26, U2006, IT761, and Advance cultivars presented tomatoes with the largest scars, while the smallest was showed by H9992, BRSena, AP533 and H9553 cultivars (Table 1).

Sobreira et al. (2009) on studying postharvest salad tomato type reported that the smallest diameter peduncle scar were correlated with increased resistance at postharvest due to the reduction of water loss. In a work with bioprospection of table tomato genotypes with potential to adapt to organic farming system, Araújo (2013) noted that cultivars showing small scars were firmer. Following the authors' stream of thought, the fruits from BRSena, H9992, AP533 and H9553 cultivars can be advantageous for the post-harvest operations due to the smaller peduncle scar diameter between 5.74 and $6.53 \mathrm{~mm}$ and consequently with higher potential to retain moisture and lower turgor loss. In this study, it was found that peduncle scar is positively correlated with fruit fresh weigh $\left(0.67^{\star}\right)$, and negatively 
Table 1. Biometrical characteristics of eleven processing tomato cultivars (Solanum lycopersicum). Goiânia, GO, Brazil.

\begin{tabular}{|c|c|c|c|c|c|}
\hline Cultivar & $\varnothing$ longit. $^{1}$ & $\varnothing$ cross-sect. $^{2}$ & Ped. scar ${ }^{3}$ & Peric. thick. ${ }^{4}$ & Skin thick. ${ }^{5}$ \\
\hline IT761 $^{6}$ & $60.75 b c \pm 8.1$ & $46.00 \mathrm{bcde} \pm 4.4$ & $7.72 \mathrm{ab} \pm 1.2$ & $7.59 \mathrm{a} \pm 0.9$ & $17.06 \mathrm{~b} \pm 0.8$ \\
\hline H9992 & $54.99 \mathrm{~d} \pm 5.3$ & $44.43 \mathrm{def} \pm 4.7$ & $5.84 \mathrm{~d} \pm 1.1$ & $5.97 \mathrm{c} \pm 1.0$ & $22.30 \mathrm{ab} \pm 0.6$ \\
\hline H9553 & $60.26 b c \pm 4.3$ & $46.28 \mathrm{bcd} \pm 4.4$ & $6.53 \mathrm{~cd} \pm 1.2$ & $6.74 \mathrm{~b} \pm 0.8$ & $24.60 \mathrm{ab} \pm 0.8$ \\
\hline AP533 & $61.81 b c \pm 7.4$ & $41.78 \mathrm{f} \pm 4.4$ & $5.89 \mathrm{~d} \pm 0.9$ & $5.94 \mathrm{c} \pm 1.0$ & $19.66 \mathrm{ab} \pm 1.3$ \\
\hline Advance & $61.34 b c \pm 6.7$ & $48.67 \mathrm{abc} \pm 4.9$ & $7.66 \mathrm{ab} \pm 1,0$ & $6.66 \mathrm{bc} \pm 1.1$ & $16.96 \mathrm{~b} \pm 1.8$ \\
\hline N901 & $61.61 b c \pm 6.0$ & $45.29 \mathrm{cde} \pm 4.3$ & $6.87 b c \pm 1.3$ & $6.49 b c \pm 0.8$ & $23.66 \mathrm{ab} \pm 2.3$ \\
\hline BRSena & $68.80 \mathrm{a} \pm 6.1$ & $42.57 \mathrm{ef} \pm 4.0$ & $5.74 \mathrm{~d} \pm 0,9$ & $6.53 b c \pm 0.8$ & $17.93 b \pm 2.8$ \\
\hline U2006 & $64.60 \mathrm{ab} \pm 5.2$ & $51.77 \mathrm{a} \pm 3.6$ & $7.99 \mathrm{a} \pm 1.5$ & $7.15 a b \pm 0.6$ & $20.70 \mathrm{ab} \pm 3.3$ \\
\hline HY26 & $57.12 \mathrm{~cd} \pm 4.1$ & $48.11 b c \pm 2.8$ & $8.38 \mathrm{a} \pm 1.0$ & $7.18 \mathrm{ab} \pm 0.9$ & $26.90 \mathrm{a} \pm 3.5$ \\
\hline HY37 & $57.78 \mathrm{~cd} \pm 4.0$ & $44.32 \mathrm{def} \pm 2.6$ & $6.82 b c \pm 0.8$ & $6.47 b c \pm 1.0$ & $17.86 \mathrm{~b} \pm 4.4$ \\
\hline HY68 & $58.50 \mathrm{~cd} \pm 5.4$ & $48.87 \mathrm{ab} \pm 5.2$ & $7.03 b c \pm 0.8$ & $7.06 \mathrm{ab} \pm 0.9$ & $19.63 \mathrm{ab} \pm 4.5$ \\
\hline $\mathrm{CV}^{7}$ & 9.6 & 9.1 & 15.7 & 13.5 & 12.9 \\
\hline
\end{tabular}

${ }^{1}$ Longitudinal diameter $(\mathrm{mm}) ;{ }^{2}$ cross-sectional diameter $(\mathrm{mm}) ;{ }^{3}$ peduncle scar $(\mathrm{mm}) ;{ }^{4}$ pericarp thickness $(\mathrm{mm}) ;{ }^{5}$ skin thickness (mm); ${ }^{6}$ Means in the same column followed by different letters differ by Tukey test at $5 \%$ level; ${ }^{7}$ Coefficient of variation (\%).

correlated with skin firmness of fruit in lying position $\left(-0.71^{*}\right)$, indicating the advantageous tendency for the postharvest, as above indicated.

Pericarp thickness ranged between 5.94 and $7.59 \mathrm{~mm}$, the larger values (7.59-7.06 mm) were observed in IT761, HY26, U2006 and HY68 cultivars, while the lowest values occurred in the AP533 and H9992, HY37, N901, BRSena and Advance cultivars (Table 1). In a work with processing tomato cultivars, Barrett et al. (1998) described a pericarp mean thickness between $5.5 \mathrm{~mm}$ and $8.2 \mathrm{~mm}$ for ripe tomatoes, corroborating the data obtained in the present study. The pericarp thickness is also positively correlated with peduncle scar diameter $\left(0.80^{* *}\right)$ and fruit volume $\left(0.64^{*}\right)$. Therefore it can be inferred that fruits with thinner pericarp (5.94 and $5.97 \mathrm{~mm}$ ) tend to have smaller cross-sectional and peduncle scar diameters, therefore having lower water loss and increased skin. Tomato fruit consists of pericarp and seeds attached to placenta.

The pericarp consists of exocarp, mesocarp and endocarp (Figure 1). The cells located just below the epidermis cells are much bigger, presenting thin walls and separated by intercellular spaces as seen in micrographic pictures $1 \mathrm{~B}$ to $1 \mathrm{~L}$. According to Barrett et al. (1998) such cells are polyhedral and present variation in both size and shape, which can also be confirmed in micrographic pictures of different cultivars evaluated in the present work. Epidermal thickness measures ranged from 16.96 to $26.9 \mu \mathrm{m}$ (58.60\% variation) (Table 1$)$. The HY26 cultivar presented epidermal thickness values significantly higher than the Advance, IT761, HY37, and BRSena cultivars while other cultivars did not differ among themselves.

Bargel \& Neinhuis (2005) studying table tomato found that morphological changes, especially the cuticle, are related to fruit ripening as an intense cutinization of epidermal cells walls occurs at maturity. They concluded that during tomato fruit growth and ripening, the morphological and mechanical properties of cuticle and epidermis are subject to considerable changes, so specific differences among cultivars can be noted. In the present study, significant differences between cultivars were also found. AP533, H9553, N901, and H9992 cultivars presented epidermal cells with very thick anticlinal and periclinal walls and cells just below the geometrically well-organized epidermis, which may be indicative of greater firmness of this cultivar.

According Konstankiewicz et al. (2010), mechanical properties of plant tissue depends on structural cell parameters, where tissues from smaller and geometrically organized cells has greater strength than tissues with larger cells, and also the cell size influences the traction stress in cell walls. Considering these aspects, tomatoes with thinner epidermis (between 17 and $18 \mu \mathrm{m}$ ) consisting of smaller cells, such as Advance, IT761, HY37 and BRSena cultivars, could have greater resistance to puncturing, although in this work any significant correlation between these parameters has not been noted.

The U2006 and Advance cultivars showed the heaviest fresh weight while AP533, H9992, HY37, IT761 and BRSena cultivars had the lowest (Table 2). In addition to genetic factors, fresh fruit weight is influenced by many factors such as irrigation and nutrient availability for the plant (Koetz et al., 2010). In this work, these factors were the same for all cultivars. Fresh weight has been positively correlated with fruit cross-sectional diameter $\left(0.89^{* *}\right)$ and peduncle scar $\left(0,70^{\star}\right)$, and negatively correlated with the firmness of skin under compression of fruit in lying position $\left(-0,71^{\star}\right)$. Therefore, fruits of AP533, H9992, IT761 and BRSena cultivars, as they showed lower fresh weight (56.70-70.08 g), showed increased skin resistance to compression transversally to the longitudinal fruit axis.

According to Filgueira (2008), the industry prefers tomato cultivars producing fruits with mean weight within 50 to $100 \mathrm{~g}$, which confer greater resistance to the transport, range in which all cultivars tested in this study are included. However, differences are noted even inside the range, being the most resistant the fruits weighting up to $70 \mathrm{~g}$.

U2006 cultivar showed fruits with the largest volume, followed by Advance, N901, and HY68 cultivars, while AP533, H9992, HY37, and H9553 cultivars showed the smallest (Table 2). Fruit volume was positively correlated with cross-sectional diameter $\left(0.78^{\star *}\right)$. As the cross-sectional diameter was negatively correlated with firmness by compression of skin fruit in lying 
position $\left(-0.75^{* *}\right)$, it can be considered that fruits from cultivars with smaller volumes $\left(61.70-75.60 \mathrm{~cm}^{3}\right)$ present more resistant skin to compression transversally to the longitudinal axis in comparison to tomatoes from the other cultivars.
According to Nascimento et al. (2013), the highest values for table tomato density are more desirable as they increase transportation yield, and the resistance to crushing during harvest and transport operations, as tomatoes are more compact with

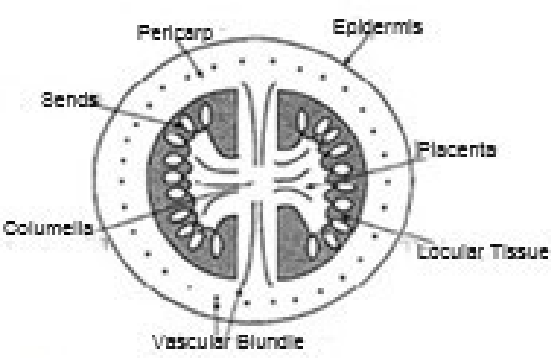

A

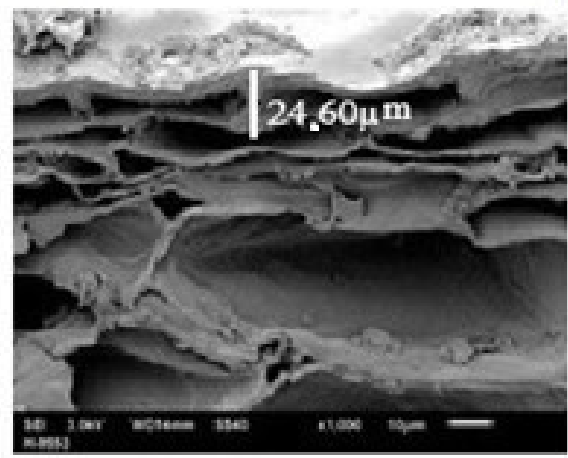

D - H9553

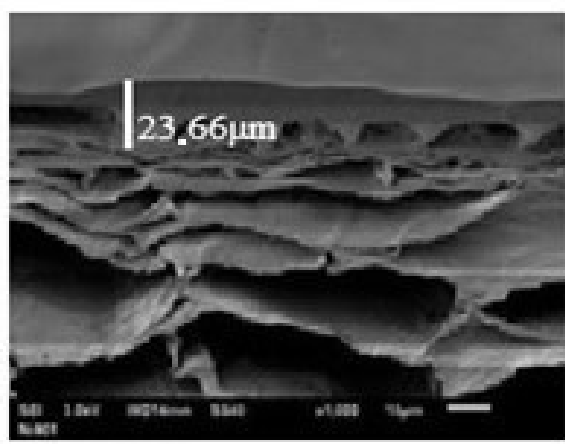

$\mathrm{G}-\mathrm{N} 901$

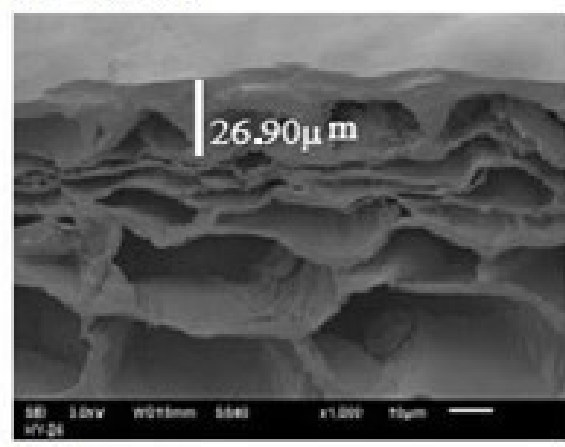

J - HY26

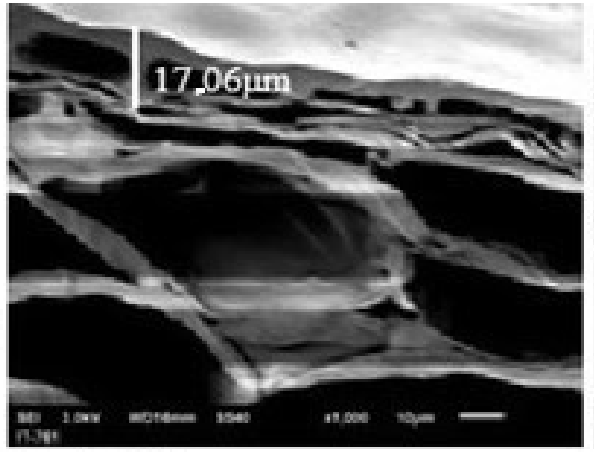

B - IT761

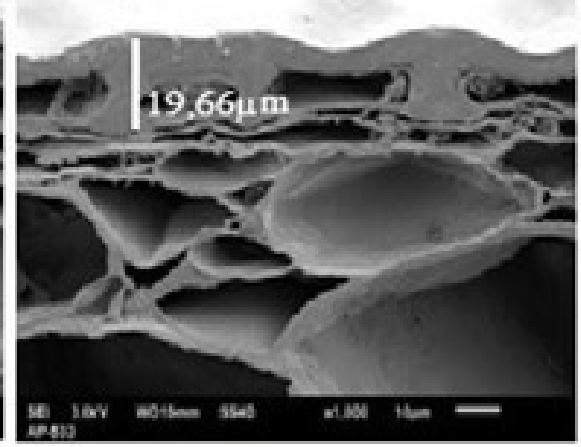

E - AP533

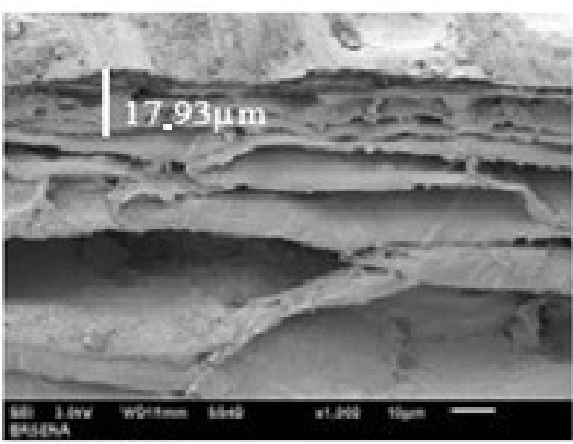

$\mathrm{H}$ - BRSena

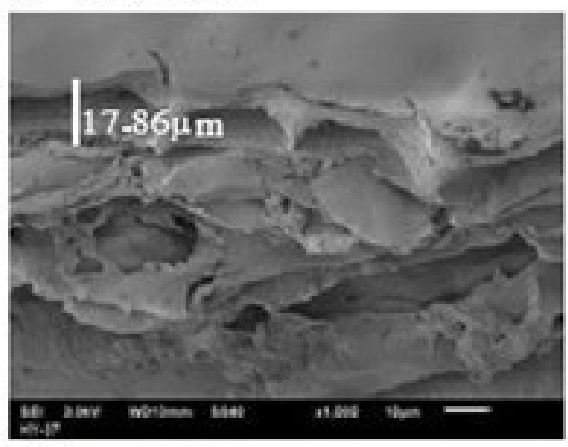

$\mathrm{K}-\mathrm{HY} 37$

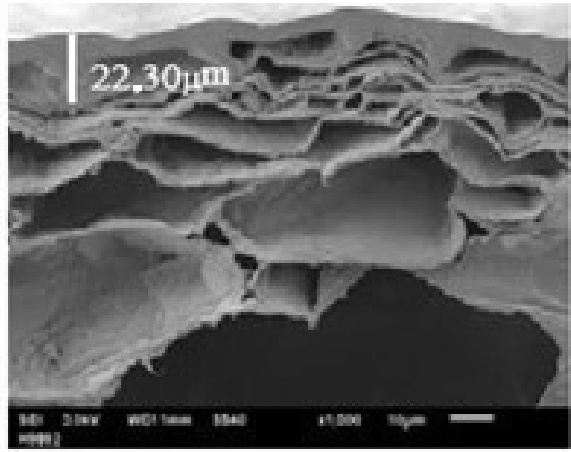

C - H9992

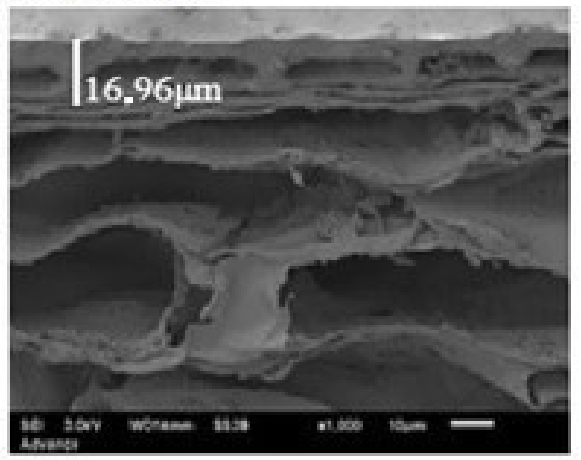

F - Advance

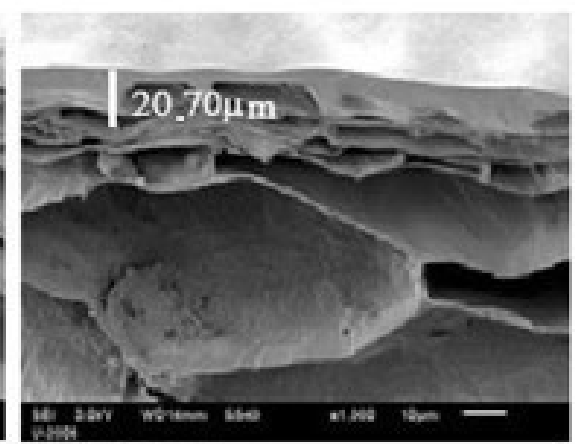

I - U2006

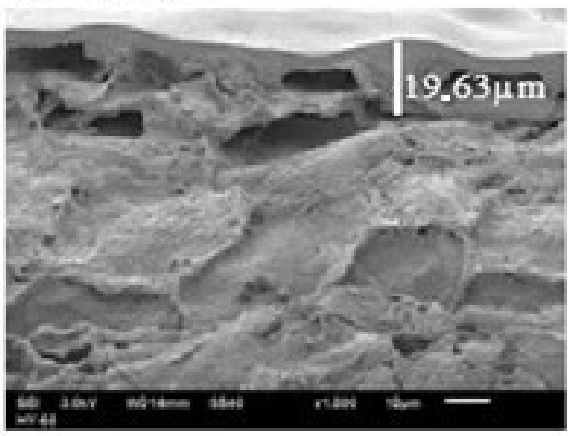

L - HY68

Figure 1. Diagram of tomato (Solanum lycopersicum) fruit (A) and scan photomicrographs of processing tomato (Solanum lycopersicum) cultivars (B to L) with mesocarp sections at full maturity stage showing epidermis and cells just below the skin. 
Table 2. Fresh weight, volume, density, moisture, ash and pectin of processing tomato cultivars (Solanum lycopersicum L.). Goiânia, GO, Brazil.

\begin{tabular}{ccccrrr}
\hline Cultivar & Fresh weight & \multicolumn{1}{c}{ Volume $^{2}$} & \multicolumn{1}{c}{ Density } & \multicolumn{1}{c}{ Moisture $^{4}$} & Ash $^{4}$ & Pectin $^{5}$ \\
\hline IT761 & $68.04 \mathrm{~cd} \pm 18.38$ & $80.66 \mathrm{bcd} \pm 25.16$ & $0.87 \mathrm{~b} \pm 0.19$ & $96.57 \mathrm{a} \pm 0.10$ & $0.34 \mathrm{~cd} \pm 0.01$ & $0.26 \mathrm{e} \pm 0.0033$ \\
H9992 & $62.02 \mathrm{~cd} \pm 18.08$ & $66.10 \mathrm{de} \pm 19.22$ & $0.94 \mathrm{ab} \pm 0.06$ & $96.01 \mathrm{ab} \pm 0.08$ & $0.39 \mathrm{abc} \pm 0.03$ & $0.23 \mathrm{f} \pm 0.0031$ \\
H9553 & $74.75 \mathrm{bc} \pm 15.93$ & $75.60 \mathrm{bcde} \pm 16.01$ & $0.98 \mathrm{a} \pm 005$ & $95.01 \mathrm{bc} \pm 0.59$ & $0.43 \mathrm{a} \pm 0.02$ & $0.47 \mathrm{a} \pm 0.0027$ \\
AP533 & $5.70 \mathrm{~d} \pm 16.93$ & $61.70 \mathrm{e} \pm 15.33$ & $0.92 \mathrm{ab} \pm 0.14$ & $96.44 \mathrm{a} \pm 0.08$ & $0.37 \mathrm{bcd} \pm 0.01$ & $0.22 \mathrm{f} \pm 0.0031$ \\
Advance & $83.02 \mathrm{ab} \pm 20.32$ & $90.00 \mathrm{ab} \pm 20.42$ & $0.94 \mathrm{ab} \pm 0.19$ & $96.06 \mathrm{ab} \pm 0.06$ & $0.41 \mathrm{ab} \pm 0.02$ & $0.36 \mathrm{c} \pm 0.0037$ \\
N901 & $73.61 \mathrm{bc} \pm 20.22$ & $84.06 \mathrm{abc} \pm 21.89$ & $0.88 \mathrm{ab} \pm 0.11$ & $94.66 \mathrm{c} \pm 0.53$ & $0.41 \mathrm{ab} \pm 0.01$ & $0.29 \mathrm{~d} \pm 0.0034$ \\
BRSena & $70.08 \mathrm{bcd} \pm 15.13$ & $79.74 \mathrm{bcd} \pm 15.10$ & $0.87 \mathrm{~b} \pm 0.08$ & $96.10 \mathrm{ab} \pm 0.28$ & $0.33 \mathrm{~d} \pm 0.02$ & $0.39 \mathrm{~b} \pm 0.0040$ \\
U2006 & $92.20 \mathrm{a} \pm 17.26$ & $96.00 \mathrm{a} \pm 16.39$ & $0.96 \mathrm{ab} \pm 0.10$ & $96.60 \mathrm{a} \pm 0.45$ & $0.32 \mathrm{~d} \pm 0.01$ & $0.25 \mathrm{e} \pm 0.0424$ \\
HY26 & $74.74 \mathrm{bc} \pm 12.72$ & $77.23 \mathrm{bcd} \pm 13.29$ & $0.97 \mathrm{ab} \pm 0.09$ & $95.95 \mathrm{ab} \pm 0.28$ & $0.32 \mathrm{~d} \pm 0.01$ & $0.22 \mathrm{f} \pm 0.0029$ \\
HY37 & $64.74 \mathrm{~cd} \pm 9.03$ & $69.47 \mathrm{cde} \pm 9.10$ & $0.93 \mathrm{ab} \pm 0.11$ & $962.4 \mathrm{a} \pm 0.10$ & $0.40 \mathrm{ab} \pm 0.02$ & $0.22 \mathrm{f} \pm 0.0025$ \\
HY68 & $74.79 \mathrm{bc} \pm 20.69$ & $80.93 \mathrm{abcd} \pm 22.29$ & $0.94 \mathrm{ab} \pm 0.21$ & $96.20 \mathrm{a} \pm 0.43$ & $0.37 \mathrm{bcd} \pm 0.01$ & $0.23 \mathrm{f} \pm 0.0034$ \\
CV & 23.71 & 25.73 & 16.72 & 0.42 & 5.25 & 4.87 \\
\hline
\end{tabular}

${ }^{1} \mathrm{~g} ;{ }^{2} \mathrm{~cm}^{3} ;{ }^{3} \mathrm{~g} \mathrm{~cm}^{-3} ;{ }^{4} \mathrm{~g} 100 \mathrm{~g}^{-1} ;{ }^{5} \mathrm{mg} 100 \mathrm{~g}^{-1} ;{ }^{6}$ Means followed by different letters in the same column differ by Tukey test at $5 \%$ level; ${ }^{7}$ Coefficient of variation (\%).

less internal cavity volume, characteristics that were not observed in this study. Fruit density ranged from 0.87 to $0.98 \mathrm{~g} \mathrm{~cm}^{-3}$, with IT761 and BRSena cultivars showing the lowest values and H9553 cultivar showing the highest, while the others did not differ among themselves, presenting fruits with intermediate density (Table 2).

Chemical composition of processing tomatoes was significantly variable among cultivars. Moisture ranged from

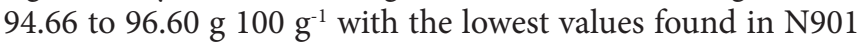
and H9553 cultivars (Table 2). Moisture content has influence on the physical, mechanical, electrical, thermal and chemical properties, as well as acting on storage stability and behavior of materials during processing (Shirmohammadi et al., 2014). Investigating the role of moisture content in mechanical behavior of materials, Blahovec (2007) found that water content in agricultural material behaves as a plasticizer.

Ash content in tomato with seeds and peels ranged from

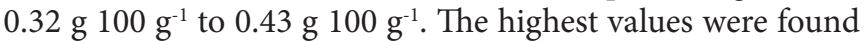
in ashes from H9553, Advance, N901, and HY37 cultivars, and the smaller values in U2006, HY26, BRSena, IT761, AP533 and HY68 cultivars (Table 2 ). There was a negative correlation between ash levels and moisture $\left(-0.63^{\star}\right)$. Isack \& Monica (2013) and Ferreira et al. (2010), working with table tomato found ash

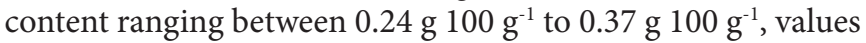
lower than those obtained in the present work. The physical and chemical fruit characteristics presented vary according to the genetic factor, place of cultivation, cultivation management, harvest season, stage of maturity, among others (Santos et al., 2010).

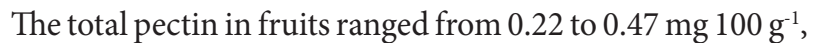
with $\mathrm{H} 9553$ cultivar presenting the highest value followed by BRSena, while AP533, HY26, HY37, H9992 and HY68 cultivars showed the lowest (Table 2). These values are within the range reported by Canteri et al. (2012), 0.2 to $0.6 \mathrm{mg}$ in $100 \mathrm{~g}^{-1}$ of tomato fresh weight.

Softening is a relevant event in climacteric fruits such as tomatoes, and occurs due to solubilization and depolymerization of pectin, middle lamella and cell wall by several hydrolases (Rose et al., 2004).
The collapsing of fruit structures is responsible for changing texture during ripening and consequently their mechanical resistance, but the precise role of changes in cell wall, and the specific enzymatic changes responsible for those events are still unknown (Hyodo et al., 2013). However, in this study the total pectin content was not correlated with other measured variable, including firmness under compression and puncture.

\subsection{Mechanical and textural characteristics}

The curve of compression force $(\mathrm{N})$ versus deformation $(\mathrm{mm})$ presented a linear and positive pattern before skin breaking point (Fm) in all cultivars evaluated in this work, and then irregular, negative and with slight return to positive before pulp breaking point $(\mathrm{Lm})$. The maximum force to break skin $(\mathrm{Fm})$, represented the maximum elastic deformation of epidermal tissue region and Lm maximum force to break mesocarp tissues (pulp). In compression test, the application of growing perpendicular force to the cross-sectional and longitudinal tomato axes (in standing or lying positions, respectively) caused an increase of fruit internal pressure and deformation until the moment of epicarp or skin rupture. The values obtained for maximum force (Fm) for breaking tomato skin, as well as the force required to break the pulp (Lm) were used to calculatethe firmness of fruit skin and pulp under compression in both standing and lying positions (Table 3 ) and firmness by puncturing skin and pulp on fruit equatorial region in lying position (Table 4).

Firmness is the ratio between employed force $(\mathrm{N})$ and deformation $(\Delta)$ (Sirisomboon et al., 2012). The skin firmness under compression in standing position ranged between 3.68 and $5.96 \mathrm{~N} \mathrm{~mm}^{-1}(61.95 \%)$. The highest values were found in IT761, N901 and HY37 cultivars, and the lowest in U2006 and HY26 cultivars, while the others showed intermediate values (Table 3 ). As transverse diameter was negatively correlated with skin firmness under compression in lying position $\left(-0.75^{\star \star}\right)$, therefore, it can be assumed that fruits of cultivars with lower volumes, between 61.70 and $75.60 \mathrm{~cm}^{3}$ presented a skin more resistant to compression transversely to the longitudinal axis regarding tomatoes from the other cultivars. According to Nascimento et al. (2013), higher density values for table tomato are more desirable, considering they are more compact and 
Table 3. Skin $\left(\mathrm{Fc}_{\text {skin }}\right)$ and pulp $\left(\mathrm{Fc}_{\text {pulp }}\right)$ firmness under compression of processing tomato fruits (Solanum lycopersicum), kept in standing and lying positions. Goiânia, GO, Brazil.

\begin{tabular}{|c|c|c|c|c|}
\hline \multirow{2}{*}{ Cultivar } & \multicolumn{2}{|c|}{ Fruit stand } & \multicolumn{2}{|c|}{ Fruit lying } \\
\hline & $\mathrm{Fc}_{\text {skin }}{ }^{1}$ & $\mathrm{Fc}_{\text {pulp }}{ }^{1}$ & $\mathrm{Fc}_{\text {skin }}{ }^{2}$ & $\mathrm{Fc}_{\text {pulp }}{ }^{2}$ \\
\hline IT761 $^{3}$ & $5.96 \mathrm{Aa} \pm 0.90$ & $1.73 \mathrm{Aa} \pm 0.21$ & $6.34 \mathrm{Aa} \pm 1.06$ & $1.63 \mathrm{Ac} \pm 0.19$ \\
\hline H9992 & $5.08 \mathrm{Aabc} \pm 1.65$ & $1.50 \mathrm{Babc} \pm 01.5$ & $5.92 \mathrm{Aab} \pm 1.09$ & $1.99 \mathrm{Aabc} \pm 0.43$ \\
\hline H9553 & $5.03 \mathrm{Aabc} \pm 1.07$ & $1.53 \mathrm{Aab} \pm 0.24$ & $5.40 \mathrm{Aabc} \pm 0.89$ & $1.78 \mathrm{Aabc} \pm 0.31$ \\
\hline AP533 & $4.36 \mathrm{Babc} \pm 1.42$ & $1.10 \mathrm{Bef} \pm 0.16$ & $6.66 \mathrm{Aa} \pm 1.59$ & $2.23 \mathrm{Aab} \pm 0.34$ \\
\hline Advance & $4.74 \mathrm{Aabc} \pm 0.66$ & $1.37 \mathrm{Bbcd} \pm 0.11$ & $5.07 \mathrm{Aabc} \pm 1.21$ & $2.31 \mathrm{Aa} \pm 0.41$ \\
\hline N901 & $5.33 \mathrm{Aab} \pm 0.73$ & $1.28 \mathrm{Bcde} \pm 0.16$ & $5.30 \mathrm{Aabc} \pm 1.24$ & $1.89 \mathrm{Aabc} \pm 0.80$ \\
\hline BRSena & $4.37 \mathrm{Babc} \pm 0.54$ & $1.08 \mathrm{Bef} \pm 0.15$ & $5.33 \mathrm{Aabc} \pm 1.01$ & $1.56 \mathrm{Ac} \pm 0.25$ \\
\hline U2006 & $3.68 \mathrm{Ac} \pm 0.84$ & $0.98 \mathrm{Bf} \pm 0.14$ & $4.26 \mathrm{Abc} \pm 1.22$ & $2.04 \mathrm{Aabc} \pm 0.40$ \\
\hline HY26 & $3.91 \mathrm{Abc} \pm 0.59$ & $1.23 \mathrm{Bde} \pm 0.16$ & $3.65 \mathrm{Ac} \pm 0.76$ & $1.55 \mathrm{Ac} \pm 0.36$ \\
\hline HY37 & $5.28 \mathrm{Aab} \pm 0.93$ & $1.61 \mathrm{Bab} \pm 0.12$ & $5.87 \mathrm{Aab} \pm 1.87$ & $2.02 \mathrm{Aabc} \pm 0.45$ \\
\hline HY68 & $5.19 \mathrm{Aabc} \pm 2.1$ & $1.51 \mathrm{Aabc} \pm 0.18$ & $4.03 \mathrm{Ac} \pm 0.60$ & $1.72 \mathrm{Abc} \pm 0.51$ \\
\hline $\mathrm{CV}^{4}$ & 22.59 & 12.36 & 22.64 & 27.35 \\
\hline
\end{tabular}

${ }^{1}$ Fruit compression standing; ${ }^{2}$ compression lying fruit; ${ }^{3}$ Mean values followed by different letters in the same column differ among themselves by Tukey test at $5 \%$ level; ${ }^{4}$ Coefficient of variation (\%).

Table 4. Skin $\left(\mathrm{Fp}_{\text {skin }}\right)$ and pulp $\left(\mathrm{Fp}_{\text {pulp }}\right)$ firmness by puncture of processing tomato (Solanum lycopersicum), kept in standing and lying position. Goiânia, GO, Brazil.

\begin{tabular}{crr}
\hline Cultivar & \multicolumn{1}{c}{$\mathrm{Fp}_{\text {skin }}{ }^{1}$} & \multicolumn{1}{c}{$\mathrm{Fp}_{\text {pulp }}{ }^{2}$} \\
\hline $\mathrm{IT761}^{3}$ & $1.87 \mathrm{ab} \pm 0.41$ & $0.22 \mathrm{abc} \pm 0.04$ \\
$\mathrm{H} 9992$ & $1.94 \mathrm{ab} \pm 0.44$ & $0.26 \mathrm{ab} \pm 0.03$ \\
$\mathrm{H} 9553$ & $1.94 \mathrm{ab} \pm 0.33$ & $0.23 \mathrm{abc} \pm 0.02$ \\
$\mathrm{AP533}$ & $2.47 \mathrm{a} \pm 0.34$ & $0.26 \mathrm{ab} \pm 0.09$ \\
Advance & $1.79 \mathrm{ab} \pm 0.35$ & $0.23 \mathrm{abc} \pm 0.04$ \\
N901 & $2.10 \mathrm{ab} \pm 0.28$ & $0.22 \mathrm{abc} \pm 0.02$ \\
BRSena & $1.68 \mathrm{ab} \pm 0.38$ & $0.19 \mathrm{c} \pm 0.04$ \\
U2006 & $1.84 \mathrm{ab} \pm 0.56$ & $0.20 \mathrm{bc} \pm 0.04$ \\
HY26 & $1.48 \mathrm{~b} \pm 0.29$ & $0.20 \mathrm{bc} \pm 0.03$ \\
HY37 & $2.09 \mathrm{ab} \pm 0.36$ & $0.19 \mathrm{c} \pm 0.04$ \\
HY68 & $2.17 \mathrm{ab} \pm 1.67$ & $0.27 \mathrm{a} \pm 0.06$ \\
$\mathrm{CV}^{4}$ & 32.02 & 19.98 \\
\hline
\end{tabular}

${ }^{1}$ Skin puncture; ${ }^{2}$ pulp puncture; ${ }^{3}$ Mean values followed by different letters in the same column differ among themselves by Tukey test at $5 \%$ level; ${ }^{4}$ Coefficient of variation (\%).

present smaller internal cavities and consequently improving transport yield and increasing resistance to deformation during harvest and transport, aspects not observed in this study.

Fruit density varied between 0.87 and $0.98 \mathrm{~g} \mathrm{~cm}^{-3}$, with IT761 and BRSena cultivars showing the lowest values and H9553 cultivar showing the greatest, while the other cultivars have no differences among themselves presenting fruits with intermediate densities. The skin firmness under compression of fruit in lying position ranged between 3.65 and $6.66 \mathrm{~N} \mathrm{~mm}^{-1}$ (82.46\%) with the highest values observed in AP533, IT761, H9992 and HY37 cultivars, and the lowest values in HY26, HY68 and U2006 cultivars. Skin firmness by compression of fruit in lying position is negatively correlated with cross-sectional diameter $\left(-0.75^{\star *}\right)$ and fresh weight $\left(-0.71^{\star}\right)$.

Thus, AP533, IT761, H9992, HY37 and BRSena cultivars are the most resistant to compressive force perpendicular to the longitudinal fruit axis (in lying position), which present lower fresh weight values and cross-sectional diameter. Bui et al. (2010), working with tomatoes in different stages of maturation, found a skin firmness of $4.94 \mathrm{~N} \mathrm{~mm}^{-1}$ in mature fruit, a data that corroborates those obtained in this research. According to Li et al. (2012), the resistance of skin tissue occurs due to the fact that exocarp tissue cells are small, compact and present dense arrangement with thick cell walls, as observed in the present study.

The pulp firmness under compression of fruit in lying position ranged from 1.55 to $2.31 \mathrm{~N} \mathrm{~mm}^{-1}$ (49.03\%), where the highest values were found in Advance and AP533 cultivars, and the lowest values in HY26, BRSena, IT761 and HY68 cultivars. The skin firmness under compression of tomato in lying position of AP533 and BRSena cultivars was higher than in standing position. However, in the other cultivars there was no difference regarding fruit positioning. Regarding pulp, no difference was observed only in IT761 and HY68 cultivars. In the other cultivars the pulp showed the greatest firmness with fruit in lying position. According to Barrett et al. (1998), the compression test is insensitive to the tissue properties and it is more influenced by the fruit shape, size and proportions of different tissues. However, pulp resistance is always lower than the exocarp resistance, indicating the real role of skin in mechanical protection of tomato, but a strong external mechanical shock can injure the pulp while skin may still be intact (Bui et al ., 2010).

In puncture test, the skin firmness of fruit on equatorial area showed a variation of $66.89 \%$ (Table 4 ). The highest skin firmness by puncture was observed in AP533 cultivar, which significantly differed only from HY26 cultivar that showed the lowest firmness. The highest pulp firmness values regarding puncture occurred in HY68, H9992 and AP533 cultivars, and the lowest values in HY37, BRSena, HY26 and U2006. HY37, IT761, H9992 and AP533 cultivars were the most resistant in mechanical and textural characterization tests, as they presented smallest fruits and lowest fresh weigh values.

HY37 and IT761 cultivars showed the highest values for pulp and skin firmness under compression of fruit in standing 
position, for skin firmness to compression of fruit in lying position, and greatest pulp firmness by puncture, while $\mathrm{H} 9992$ cultivar showed the greatest pulp firmness under compression of fruit in standing position, and skin firmness on fruit in lying position. AP533 cultivar presented the greatest firmness under compression of skin and pulp of fruit in lying position and the greatest skin and pulp firmness by puncture.

In this study, the standing fruits, i.e. with peduncle scar down the texturometer platform, required greater compression force to break the fruit epiderm. Scott et al. (2008) analyzing the firmness of ripe tomatoes in laying position on texturometer platform with force being applied in equatorial region, obtained values between 2.77 and $3.33 \mathrm{~N} \mathrm{~mm}^{-1}$, values lower than those observed in the same position in this study, considering that in such study table tomatoes were used. However, Matas et al. (2004) studying the biomechanics and anatomy of tomato skin when positioned equatorially and longitudinally, observed that cuticular layer is isotropic, i.e., the mechanical behavior is indifferent to the direction of applied force. However, in this research it was found that fruit position influences the amount of force required to break it.

\section{Conclusion}

Physical, chemical and mechanical characteristics of fruits are dependent on cultivar;

In general terms, fruits more resistant to compression and puncture present lower longitudinal, transverse, and scar peduncle diameters, pericarp thickness, fresh weight, volume, and higher moisture and pectin contents;

Cultivars with lower fresh weight have the best mechanical characteristics, being the most recommended for harvesting, handling and bulk transport;

AP533, IT761, HY37 and H9992 cultivars showed the best mechanical resistance among the cultivars studied.

\section{References}

Association of Official Analytical Chemists - AOAC. (2012). Official methods of analysis of AOAC (19th ed.). Gaitlerburg: AOAC International.

Araújo, J. C. (2013). Bioprospecção de genótipos de tomate de mesa (Solanum lycopersicum L.) com potencial de adaptação ao sistema de cultivo orgânico [Master's thesis]. Escola Superior de Agricultura "Luiz de Queiroz, Universidade de São Paulo, Piracicaba.

Bargel, H., \& Neinhuis, C. (2005). Tomato (Lycopersicon esculentum Mill.) fruit growth and ripening as related to the biomechanical properties of fruit skin and isolated cuticle. Journal of Experimental Botany, 56(413), 1049-1060. http://dx.doi.org/10.1093/jxb/eri098. PMid:15710631.

Barrett, D. M., Garcia, E., \& Wayne, J. E. (1998). Textural modification of processing tomatoes. Critical Reviews in Food Science and Nutrition, 38(3), 173-258. http://dx.doi.org/10.1080/10408699891274192. PMid:9595227.

Blahovec, J. (2007). Role of water content in food and product texture. International Agrophysics, 21, 209-215.

Blumenkrantz, N., \& Asboe-Hansen, G. (1973). New method for quantitative determination of uronic acids. Analytical Biochemistry,
54(2), 484-489. http://dx.doi.org/10.1016/0003-2697(73)90377-1. PMid:4269305.

Bui, H.-T., Makhlouf, J., \& Ratti, C. (2010). Postharvest ripening characterization of greenhouse tomatoes. International Journal of Food Properties, 13(4), 830-846. http://dx.doi.org/10.1080/10942910902895234.

Canteri, M. H. G., Gilvan Wosiacki, L. M., \& Scheer, A. D. P. (2012). Pectina: da matéria-prima ao produto final. Polímeros, São Carlos, 22(2), 149-157. http://dx.doi.org/10.1590/S0104-14282012005000024.

Dimitrios, B., Magdalini, K., Ioannis, R., Panayiota, P., Ilias, T., Nikolina, C., \& Argyro, D. (2018). Effects of organic and inorganic fertilization on yield and quality of processing tomato (Lycopersicon esculentum Mill.). Folia Horticulturae, 30(2), 321-332. http://dx.doi.org/10.2478/ fhort-2018-0027.

Ferreira, S. M. R., Freitas, R. J. S. D., Karkle, E. N. L., Quadros, D. A. D., Tullio, L. T., \& Lima, J. J. D. (2010). Qualidade do tomate de mesa cultivado nos sistemas convencional e orgânico. Food Science and Technology (Campinas), 30(1), 224-230. http://dx.doi.org/10.1590/ S0101-20612010000100033.

Filgueira, F. A. R. (2008). Novo manual de olericultura: agrotecnologia moderna na produção e comercialização de hortaliças (3. ed., 421 p.). Viçosa: UFV;

Hyodo, H., Terao, A., Furukawa, J., Sakamoto, N., Yurimoto, H., Satoh, S., \& Iwai, H. (2013). Tissue specific localization of pectin-Ca2+ cross-linkages and pectin methyl-esterification during fruit ripening in tomato (Solanum lycopersicum). PLoS One, 8(11), 78949. http:// dx.doi.org/10.1371/journal.pone.0078949. PMid:24236073.

Isack, M. E., \& Monica, L. (2013). Effect of post-harvest handling practices on physico-chemical composition of tomato. Agricultural Technology (Thailand), 9, 1655-1664.

Koetz, M., Masca, M. G. C. C., Carneiro, L. C., Ragagnin, V. A., Sena, D. G. Jr., \& Gomes, R. R. Fo. (2010). Caracterização agronômica e `brix em frutos de tomate industrial sob irrigação por gotejamento no sudoeste de Goiás. Revista Brasileira de Agricultura Irrigada, 4(1), 14-22. http://dx.doi.org/10.7127/rbai.v4n100022.

Konstankiewicz, K., Pawlak, K., \& Zdunek, A. (2010). Influence of structural parameters of potato tuber cells on their mechanical properties. International Agrophysics, 4, 243-246.

Li, Z., Li, P., Yang, H., Liu, J., \& Xu, Y. (2012). Mechanical properties of tomato exocarp, mesocarp and locular gel tissues. Journal of Food Engineering, 111(1), 82-91. http://dx.doi.org/10.1016/j. jfoodeng.2012.01.023.

Li, Z., Miao, F., \& Andrews, J. (2017). Mechanical models of compression and impact on fresh fruits. Comprehensive Reviews in Food Science and Food Safety, 16(6), 1296-1312. http://dx.doi.org/10.1111/15414337.12296.

Li, Z., \& Thomas, C. (2016). Multiscale biomechanics of tomato fruits: a review. Critical Reviews in Food Science and Nutrition, 56(7), 1222-1230. http://dx.doi.org/10.1080/10408398.2012.7599 02. PMid:25674836.

Matas, A. J., Cobb, E. D., Bartsch, J. A., Paolillo, D. J. Jr., \& Niklas, K. J. (2004). Biomechanics and anatomy of Lycopersicon esculentum fruit peels and enzyme-treated samples. American Journal of Botany, 91 (3), 352-360. http://dx.doi.org/10.3732/ajb.91.3.352. PMid:21653391.

McCready, R., \& McComb, E. A. (1952). Extraction and determination of total pectic materials in fruits. Analitycal Chemistry, 24(12), 1986-1988. http://dx.doi.org/10.1021/ac60072a033.

Nascimento, A. R., Soares, M. S. Jr., Caliari, M., Fernandes, P. M., Rodrigues, J. P. M., \& Carvalho, W. T. (2013). Qualidade de tomates de mesa cultivados em sistema orgânico e convencional no estado 
de Goiás. Horticultura Brasileira, 31(4), 628-635. http://dx.doi. org/10.1590/S0102-05362013000400020.

Pirrello, J., Regad, F., Latche, A., Pech, J.-C., \& Bouzayen, M. (2009). Regulation of tomato fruit ripening. Perspectives in Agriculture, Veterinary Science, Nutrition and Natural Resources, 4(051), 1-14. http://dx.doi.org/10.1079/PAVSNNR20094051.

Radzevičius, A., Viškelis, P., Viškelis, J., Karklelienè, R., Juškevičienė, D., \& Duchovskis, P. (2016). Tomato biochemical composition and quality attributes in different maturity fruits. Acta Scientiarum Polonorum. Hortorum Cultus, 15, 221-231.

Rose, J. K., Saladié, M., \& Catalá, C. (2004). The plot thickens: new perspectives of primary cell wall modification. Current Opinion in Plant Biology, 7(3), 296-301. http://dx.doi.org/10.1016/j.pbi.2004.03.013. PMid:15134750.

Santos, M. B. D., Cardoso, R. L., Fonseca, A. A. D. O., \& Conceição, M. D. N. (2010). Characterization and quality of umbu-caja fruits (Spondiastuberosa X S. mombin) procceeding from the Southern Reconcavo in Bahia. Revista Brasileira de Fruticultura, 32, 1089-1097. http://dx.doi.org/10.1590/S0100-29452011005000015.

Schneider, C. A., Rasband, W. S., \& Eliceiri, K. W. (2012). NIH Image to ImageJ: 25 years of image analysis. Nature Methods, 9(7), 671-675. http://dx.doi.org/10.1038/nmeth.2089. PMid:22930834.
Scott, J. W., Baldwin, E. A., Klee, H. J., Brecht, J. K., Olson, S. M., Bartz, J. A., \& Sims, C. A. (2008). Fla. 8153 hybrid tomato; Fla. 8059 and Fla. 7907 breeding lines. HortScience, 43(7), 2228-2230. http:// dx.doi.org/10.21273/HORTSCI.43.7.2228.

Shirmohammadi, M., Yarlagadda, P. K., \& Gu, Y. (2014). A constitutive model for mechanical response characterization of pumpkin peel and flesh tissues under tensile and compressive loadings. Journal of Food Science and Technology, 52(8), 4874-4884. PMid:26243907.

Sirisomboon, P., Tanaka, M., \& Kojima, T. (2012). Evaluation of tomato textural mechanical properties. Journal of Food Engineering, 111(4), 618-624. http://dx.doi.org/10.1016/j.jfoodeng.2012.03.007.

Sobreira, F. M., Sobreira, F. M., Fialho, G. S., Sánchez, C. F. B., \& Matta, F. P. (2009). Análise de trilha em pós-colheita de tomate tipo salada. Revista Facultad Nacional de Agronomía, 62, 4983-4988.

Stropek, Z., \& Golacki, K. (2015). A new method for measuring impact related bruises in fruits. Postharvest Biology and Technology, 110, 131-139. http://dx.doi.org/10.1016/j.postharvbio.2015.07.005.

Viskelis, P., Radzevicius, A., Urbonaviciene, D., Viskelis, J., Karkleliene, R., \& Bobinas, C. (2015). Biochemical parameters in tomato fruits from different cultivars as functional foods for agricultural, industrial, and pharmaceutical uses (Chap. 3, p. 45-77). In H. ElShemy. Plants for the future. London: IntechOpen Limited. http:// dx.doi.org/10.5772/60873. 